\title{
Purification of Human Erythroid Colony-forming Units and Demonstration of Specific Binding of Erythropoietin
}

\author{
K. Sawada, S. B. Krantz, J. S. Kans, E. N. Dessypris, S. Sawyer, A. D. Glick, and C. I. Civin \\ Departments of Medicine and Pathology, Vanderbilt University School of Medicine, and Veterans Administration Medical Center, \\ Nashville, Tennessee 37232, and The Johns Hopkins Oncology Center, Baltimore, Maryland 21205
}

\begin{abstract}
Morphological and biochemical studies of human colony-forming units-erythroid (CFU-E) have been hindered by their extreme rarity. Since burst-forming units-erythroid (BFU-E) develop into CFU-E, we used normal human blood BFU-E to generate large numbers of highly purified CFU-E in vitro. Using density centrifugation, sheep erythrocyte rosetting, surface immunoglobulinpositive cell depletion, adherence to plastic, and negative panning with monoclonal antibodies, human blood BFU-E were purified from 0.017 to $0.368 \%$, a 22 -fold purification with a $43 \%$ yield. The panned cells were cultured in methylcellulose with recombinant erythropoietin (rEp) and conditioned medium for 9 d. These cells were then collected and CFU-E were further purified using adherence and density centrifugation. This yielded almost $10^{7}$ erythroid colony forming cells with a purity of $70 \pm 18 \%$. Analysis of these cells by light and electron microscopy showed 94\% erythroid cells. The prominent cell was a primitive blast with high nuclear/cytoplasmic ratio, dispersed nuclear chromatin and a distinct large nucleolus. The relation between the number of erythroid colonies and the number of day 9 cells plated in plasma clots was a straight line through the origin with a maximum number of erythroid colonies at $1 \mathrm{U} / \mathrm{ml}$ of $\mathrm{rEp}$ and no erythroid colonies without $\mathbf{r E p}$. Specific binding with ${ }^{125} \mathrm{I}-\mathrm{rEp}$ showed that $60 \%$ of the binding was inhibited by excess pure erythropoietin (Ep), but not by albumin, fetal calf serum, and a variety of growth factors or glycoproteins. By days 12-13 of cell culture, when the progenitor cells matured to late erythroblasts, specific binding markedly declined. In this study, human CFU$\mathbf{E}$ have been isolated in sufficient purity to characterize the morphology of these rare cells and in sufficient numbers to measure specific binding of Ep.
\end{abstract}

\section{Introduction}

The study of the development of normal human erythroid progenitor cells, as well as diseased human progenitor cells has been hindered by a lack of pure reagents. Pure erythropoietin (Ep) ${ }^{1}$

Address reprint requests to Dr. Krantz, Department of Medicine (Hematology), Vanderbilt Medical Center North, C3101, Nashville, TN 37232.

This work was presented in part at the 28th Annual Meeting of the American Society of Hematology in San Francisco, CA, 8 December 1986. 1987.

Received for publication 6 January 1987 and in revised form 25 March

1. Abbreviations used in this paper: $\mathrm{AB}^{-}$, antibody-negative cells; $\mathrm{AD}^{-}$, nonadherent cells; CFU-E, colony-forming units-erythroid; BFU-E, burst forming units-erythroid; CFU-GM, colony-forming units-granulocyte

The Journal of Clinical Investigation, Inc.

Volume 80, August 1987, 357-366
(1) and recombinant Ep (rEp) (2) can now be obtained, but sufficient numbers of pure target cells for the measurement of biochemical alterations, or the characterization of membrane receptors, are readily available only in the murine system (3). Human burst-forming units-erythroid (BFU-E) have been highly purified from fetal liver and bone marrow tissues, but only in small numbers $(4,5)$. Because of the heterogeneity of bone marrow tissue and the low concentration of human colony-forming units-erythroid (CFU-E) in the bone marrow (6), attempts to purify these cells using physical and chemical parameters have had very limited success.

Since it has been shown that BFU-E develop into CFU-E $(7,8)$, we hypothesized that it should be possible to obtain highly purified human CFU-E in large numbers by culturing BFU-E progenitor cells found in human peripheral blood. Using the methods of density centrifugation, sheep erythrocyte rosetting, adherence to plastic dishes, and immunoadsorption (panning), human BFU-E derived from peripheral blood were partially purified, and were then cultured in methylcellulose in the presence of $\mathrm{rEp}$ for $9 \mathrm{~d}$. Erythroid bursts that proliferated in the methylcellulose culture medium were collected and further purified using adherence to plastic dishes to remove remaining monocytes and macrophages, while dead cells and debris were removed by density centrifugation. These methods provided uniformly developed CFU-E in sufficient numbers to measure Ep binding as previously reported for murine CFU-E (9).

The successful analysis of the molecular events that control CFU-E development depends on the purity, uniformity of maturation and number of these target cells. We demonstrate the isolation of human CFU-E that sufficiently meet these parameters to allow characterization of their morphology and measurement of specific binding of Ep.

\section{Methods}

Blood samples. Peripheral blood was obtained from normal adult volunteers who had previously signed consent forms approved by the Vanderbilt Committee for the Protection of Human Subjects and the Veterans Administration Research and Development Committee. Approximately $400 \mathrm{ml}$ was collected in sodium heparin (Upjohn Co., Kalamazoo, MI) at a final concentration of $20 \mathrm{U} / \mathrm{ml}$.

Cell separation by density centrifugation. Light density mononuclear peripheral blood cells were separated over Ficoll-Hypaque (FH; 1.077 $\mathrm{g} / \mathrm{cm}^{3}$; Pharmacia Fine Chemicals, Piscataway, NJ; Winthrop-Breton Laboratories, New York) at $400 \mathrm{~g}$ for $25 \mathrm{~min}$ at $24^{\circ} \mathrm{C}(10)$. The interface mononuclear FH cells were collected, washed twice with alpha minimum essential medium ( $\alpha$-MEM) containing $2 \%$ heat-inactivated fetal calf serum (FCS; Hyclone Laboratories, Logan, UT) and were resuspended in 50\% Iscove's modified Dulbecco's medium (IMDM/50\% $\alpha$-MEM;

macrophage; Ep, erythropoietin; $\mathrm{ERF}^{-}$, nonerythrocyte rosette-forming cells; FH, Ficoll-Hypaque; GCT-CM, giant cell tumor-conditioned medium; HSA, human serum albumin; IMDM, Iscove's modified Dulbecco's medium; MC, methylcellulose; $\alpha$-MEM, alpha minimum essential medium; $\mathrm{SIg}^{-}$, surface immunoglobin-negative cells. 
both from Sigma Chemical Co., St. Louis, MO) at a concentration of 5 $\times 10^{6}$ nucleated cells per $\mathrm{ml}$.

Sheep erythrocyte rosette-forming cell depletion. Sheep red blood cells (Cappel Laboratories, Cochranville, PA) were washed three times with phosphate-buffered saline (PBS) and were resuspended in $\alpha$-MEM at a concentration (vol/vol) of $0.5 \%$ (11). The $\mathrm{FH}$ light density mononuclear blood cells and sheep erythrocytes were mixed in equal volumes, and were incubated for $5 \mathrm{~min}$ in a $37^{\circ} \mathrm{C}$ water bath. After centrifugation at $130 \mathrm{~g}$ for $10 \mathrm{~min}$ at $24^{\circ} \mathrm{C}$, two-thirds of the supernatant was removed, and the cells were incubated in the presence of $50 \mu$ l of heat-inactivated pooled human $\mathrm{AB}$ serum for $60 \mathrm{~min}$ at $4^{\circ} \mathrm{C}$. The cell pellet was then gently dispersed, and the cell suspension was centrifuged over $\mathrm{FH}$ at 400 $g$ for $15 \mathrm{~min}$ at $24^{\circ} \mathrm{C}$. The interface mononuclear cells (ERF-) were collected, washed twice, and resuspended in 50\% IMDM/50\% $\alpha$-MEM containing 2\% FCS.

Surface immunoglobulin-positive cell depletion. A modification of the method reported by Chess et al. (12) was used. The ERF- cells were incubated at $4^{\circ} \mathrm{C}$ for $80 \mathrm{~min}$ in $100 \times 20 \mathrm{~mm}$ plastic tissue culture dishes (Becton Dickinson Co., Oxnard, CA) that had been previously coated with affinity-purified sheep anti-human $\mathrm{IgG}$ specific for the $\mathrm{F}(\mathrm{ab})_{2}$ fragment (Cappel Laboratories, Malvern, PA). The cell concentration was $5 \times 10^{6}$ nucleated cells $/ \mathrm{ml}$ and $5 \mathrm{ml}$ were applied to each plate. The nonadherent cells $\left(\mathrm{SIg}^{-}\right)$were removed with two gentle washes and the cells were centrifuged at $400 \mathrm{~g}$ for $10 \mathrm{~min}$ at $24^{\circ} \mathrm{C}$.

Adherent cell depletion. The $\mathrm{ERF}^{-}, \mathrm{SIg}^{-}$mononuclear cells were resuspended in $50 \%$ IMDM/50\% $\alpha$-MEM with ribonucleosides and deoxyribonucleosides, containing $20 \%$ FCS and $10 \%$ GCT conditioned medium (GCT-CM) (Gibco Laboratories, Grand Island, NY). $10 \mathrm{ml}$ of the cell suspension, at a concentration of $5 \times 10^{6}$ nucleated cells $/ \mathrm{ml}$, were incubated in $75 \mathrm{~cm}^{2}$ tissue culture polystyrene flasks (Becton Dickinson \& Co.) overnight at $37^{\circ} \mathrm{C}$ in a $5 \% \mathrm{CO}_{2}$ atmosphere (13). The nonadherent day 1 cells $\left(\mathrm{AD}^{-}\right)$were removed with three gentle washes and were centrifuged.

Antibody-coated cell depletion. The $\mathrm{ERF}^{-}, \mathrm{SIg}^{-}, \mathrm{AD}^{-}$day 1 mononuclear cells were cooled to $3^{\circ} \mathrm{C}$ and were suspended at $70 \times 10^{6}$ cells/ $\mathrm{ml}$ in $25 \mu \mathrm{l}$ of CD11b/OKM*1 $(20 \mu \mathrm{g} / \mathrm{ml}), 25 \mu \mathrm{l}$ of CD2/OKT ${ }^{*} 11(10$ $\mu \mathrm{g} / \mathrm{ml}$ ) (Ortho Diagnostic Systems Inc., Raritan, NJ), $50 \mu \mathrm{l}$ of CD45R/ My 11 , and $50 \mu$ lof My 23 to coat granulocytes (My $23^{+}, \mathrm{OKM}^{*} 1^{+}$), monocytes $\left(\mathrm{My} \mathrm{23}^{+}, \mathrm{OKM}^{*} 1^{+}\right)$, colony-forming units granulocyte-mac-

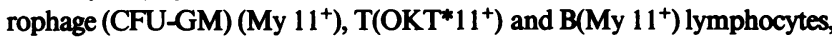
and natural killer cells $\left(\mathrm{OKM}^{*} 1^{+}, \mathrm{My} 23^{+}\right)(14-17)$. The latter two antibodies were used as spent hybridoma tissue culture supernatant. My 23 is an $\mathrm{IgG}_{1}$ monoclonal antibody raised by immunization of a mouse with normal human granulocytes. It binds selectively to granulocytes, monocytes, and natural killer cells from peripheral blood, labeling these cells intensely, but does not bind to colony-forming units (Warren, J., L. C. Strauss, and C. I. Civin, unpublished data).

The cell suspension was gently rocked on a platform at $0^{\circ} \mathrm{C}$ for 60 min and the cells were then washed twice with $\alpha$-MEM containing $2 \%$ FCS, and once with IMDM containing $2 \%$ FCS, before suspending them at $2 \times 10^{6} / \mathrm{ml}$ in IMDM containing $5 \%$ FCS $(4,5) .5$-ml aliquots were incubated at $4^{\circ} \mathrm{C}$ for $90 \mathrm{~min}$ in 100 -mm plastic tissue culture dishes that had been previously coated with affinity-purified goat anti-murine IgG (Boehringer Mannheim Biochemicals, Indianapolis, IN). The antibodynegative $\left(\mathrm{AB}^{-}\right)$nonadherent cells were removed and centrifuged.

Preparation of immunoglobulin-coated plates. Panning was carried out by the method of Wysocki and Sato (18). Plastic tissue culture dishes $(100 \times 20 \mathrm{~mm})$ were incubated at room temperature with $10 \mathrm{ml}$ of 0.05 M Tris-HCl buffer, $\mathrm{pH} 9.5$, containing $20 \mu \mathrm{g} / \mathrm{ml}$ of affinity-purified goat anti-murine IgG or $25 \mu \mathrm{g} / \mathrm{ml}$ of affinity-purified sheep anti-human IgG. After $3 \mathrm{~h}$, the plates were washed six times in PBS and once in PBS containing $1 \% \mathrm{FCS}$ and were then stored at $-20^{\circ} \mathrm{C}$ until they were used.

Culture procedure for $\mathrm{BFU}-\mathrm{E}$. The $\mathrm{ERF}^{-}, \mathrm{SIg}^{-}, \mathrm{AD}^{-}, \mathrm{AB}^{-}$day 1 mononuclear cells were cultured at a concentration of $2 \times 10^{5}$ cells $/ \mathrm{ml}$ in a mixture containing 30\% FCS (vol/vol), $1 \%$ deionized (19) human serum albumin (HSA) (American Red Cross Blood Service), $10^{-4}$ M 2 mercaptoethanol (Eastman Kodak Co., Rochester, NY), penicillin at
$500 \mathrm{U} / \mathrm{ml}$, streptomycin at $40 \mu \mathrm{g} / \mathrm{ml}, 10 \% \mathrm{GCT}-\mathrm{CM}$ (vol/vol), rEp, 10,000 $\mathrm{U} / \mathrm{mg}$ protein (AMGen Biologicals, Thousand Oaks, CA) at $2 \mathrm{U} / \mathrm{ml}$, and $0.9 \%$ methylcellulose (Fisher Scientific Co., Fair Lawn, NJ) in IMDM (20). The cells were plated in flat-bottomed 24-well tissue culture plates (Linbro, Flow Laboratories, Inc., McLean, VA) at $0.5 \mathrm{ml} /$ well and were incubated at $37^{\circ} \mathrm{C}$ in a high humidity $5 \% \mathrm{CO}_{2} / 95 \%$ air incubator. At the same time, aliquots of the cells were cultured in a $0.5-\mathrm{ml}$ plasma clot mixture containing $30 \% \mathrm{FCS}, 1 \% \mathrm{HSA}, 10^{-7} \mathrm{M} 2$-mercaptoethanol, penicillin/streptomycin, $10 \%$ GCT-CM, rEp at $2 \mathrm{U} / \mathrm{ml}, 1.3 \mathrm{mg} / \mathrm{ml}$ of fibrinogen (Fibrinogen Kabi, Grade L, Kabi Diagnostics, Stockholm, Sweden) that had been dialyzed in $300 \mathrm{ml}$ Hanks' balanced salt solution (Gibco) for $3 \mathrm{~h}, 10 \%$ bovine citrated plasma, and $0.2 \mathrm{U} / \mathrm{ml}$ of thrombin (Parke-Davis, Morris Plains, NJ) at concentrations of $1.5 \times 10^{5}-3.0 \times 10^{5}$ cells/ml $(6,10)$. BFU-E plated in plasma clots were fixed on day 15 and stained with benzidine-hematoxylin as described by McLeod et al. (19). Enumeration of BFU-E was performed in accordance with the criteria of Clark and Housman (10).

Collection of CFU-E from methylcellulose. On day 9 of incubation, $1 \mathrm{ml}$ of $\alpha$-MEM was dispersed into each well and gently mixed using a 1-ml pipette. The mixture was collected in 50-ml conical tubes (Falcon Labware, Becton Dickinson and Co.). The wells were washed again with $\alpha$-MEM containing $2 \%$ FCS and the methylcellulose (MC) cells were collected, diluted with an equal volume of $\alpha$-MEM, and were centrifuged at $600 \mathrm{~g}$ for $10 \mathrm{~min}$ at $4^{\circ} \mathrm{C}$. The MC cells were resuspended in $10 \mathrm{ml}$ of IMDM containing $2 \%$ FCS. In some experiments, the collection of cultured MC cells was carried out on days 8-13.

Adherent cell depletion from $M C$ cells. The MC cells were resuspended, at a maximum concentration of $2 \times 10^{6}$ cells/ml, in IMDM containing $20 \%$ FCS and $0.5 \mathrm{U} / \mathrm{ml}$ of $\mathrm{rEp}$, and were incubated in $25 \mathrm{~cm}^{2}$ tissue culture polystyrene flasks for $1 \mathrm{~h}$ at $37^{\circ} \mathrm{C}$ in a high humidity $5 \% \mathrm{CO}_{2}$, 95\% air incubator. The nonadherent cells $\left(\mathrm{MC}^{-}\right)^{-}$) were removed with three gentle washes and were centrifuged and resuspended in IMDM containing $2 \%$ FCS.

Viable cell enrichment of $M C A D^{-}$cells. $\mathrm{MC}^{-} \mathrm{AD}^{-}$cells were resuspended in $2 \mathrm{ml}$ of IMDM containing $2 \%$ FCS and overlaid on the top of $2 \mathrm{ml}$ of $\mathrm{FH}$ in a $12 \times 75 \mathrm{~mm}$ polystyrene tube. After centrifugation at $600 \mathrm{~g}$ for $15 \mathrm{~min}$ at $24^{\circ} \mathrm{C}$, the interface mononuclear cells (MC FH) were collected, washed three times, and resuspended in IMDM containing $2 \%$ FCS at $4^{\circ} \mathrm{C}$. The viability of these cells was measured by dye exclusion using $0.2 \%$ trypan blue dye (21).

Culture procedure for $C F U-E$. The MC FH cells were cultured at $37^{\circ} \mathrm{C}$ in a $0.5-\mathrm{ml}$ plasma clot mixture containing $15 \% \mathrm{FCS}, 15 \%$ pooled human AB serum, $1 \% \mathrm{HSA}$, penicillin/streptomycin, $1.3 \mathrm{mg} / \mathrm{ml}$ fibrinogen, $0.2 \mathrm{U} / \mathrm{ml}$ of thrombin and IMDM, with varying concentrations of rEp and varying cell concentrations. Clots were fixed and stained on day 15 of incubation ( $15 \mathrm{~d}$ after obtaining blood) and CFU-E were defined as cells that gave rise to single colonies of 8-49 hemoglobinized cells (22, 23) while erythroid colony-forming cells were defined as cells that gave rise to colonies of two or more hemoglobinized cells.

Preparation of ${ }^{125} I-r E p$. rEp was iodinated using IODO-GEN (Pierce Chemical Co., Rockford, IL by a modification of the method previously published [24, 25]). $2 \mu \mathrm{g}$ of IODO-GEN (1,3,4,6-tetrachloro-3 $\alpha, 6 \alpha$-diphenylglycouril), in $40 \mu \mathrm{l}$ of $\mathrm{CHCl}_{3}$, were evaporated onto the wall of a $300-\mu \mathrm{l}$ conical vial. $50 \mathrm{U}$ of pure rEp, 129,000 U/mg protein (AMGen) and $100 \mu \mathrm{Ci}$ of $\mathrm{Na}^{125} \mathrm{I}$ (Amersham Corp., Arlington Heights, IL) were incubated in $50 \mu \mathrm{l}$ of $0.25 \mathrm{M}$ phosphate buffer, $0.12 \mathrm{mM}$ Hepes, $\mathrm{pH} 7$, with $10 \%$ glycerol and $0.02 \%$ Tween 20 (Bio-Rad Laboratories, Richmond, CA) for $5 \mathrm{~min}$ at $24^{\circ} \mathrm{C}$. The mixture was then removed from the reaction vial and transferred to a tube containing $0.5 \mathrm{ml}$ of PBS with 5 $\mathrm{mg} \mathrm{KI}, 0.02 \%$ Tween 20 , and $0.1 \%$ bovine serum albumin (BSA) (Armour Pharmaceutical Co., Kankakee, IL). ${ }^{125}$ I-rEp was separated from free ${ }^{125}$ I by chromatography over a Bio-gel P6 DG column (Bio-Rad Laboratories), equilibrated with PBS containing $0.1 \%$ BSA and $0.02 \%$ Tween $20 .{ }^{125} \mathrm{I}-$ rEp containing no more than 0.6 molecules of ${ }^{125}$ per molecule of rEp had $>95 \%$ retention of biological activity when assayed in vitro (25).

Binding method. Microwell cluster plates (Costar, Cambridge, MA) were preincubated in a $37^{\circ} \mathrm{C}$ incubator with a humidified $5 \% \mathrm{CO}_{2}$ at- 
mosphere, or at $0^{\circ} \mathrm{C}$. An aliquot $(40 \mu \mathrm{l})$ of the cell suspension was added to each well and the cells were preincubated for $15 \mathrm{~min}$ at $37^{\circ} \mathrm{C}$, or at $0^{\circ} \mathrm{C}$, and then $10 \mu \mathrm{l}$ of ${ }^{125} \mathrm{I}-\mathrm{rEp}$, containing $0.08-0.2 \mathrm{U}$ was added. After the desired interval, $0.25 \mathrm{ml}$ of $\mathrm{PBS}$ at $0^{\circ} \mathrm{C}$ was added to each replicate and the cell suspensions were layered on $0.9 \mathrm{ml}$ of $10 \% \mathrm{BSA}$ in PBS, at $0^{\circ} \mathrm{C}$, in 1.5-ml microfuge tubes (9). The cells were separated from the radioactive medium by centrifugation at $15,300 \mathrm{~g}$ for $4 \mathrm{~min}$ at $4^{\circ} \mathrm{C}$. The tube contents were frozen using dry ice/ethanol, and the tips were then cut off above the pellet. The radioactivity of the pellet was measured in a well-type scintillation counter, using counting times sufficient to ensure precision within $3 \%$. Nonspecific binding was measured by the same method, except that a $60-80$-fold excess of unlabeled, partially purified ( $570 \mathrm{U} / \mathrm{mg}$ protein) or pure $(70,000 \mathrm{U} / \mathrm{mg}$ protein) human urinary Ep a gift of Dr. Eugene Goldwasser (1), was added with the ${ }^{125} \mathrm{I}-\mathrm{rEp}$. Specific binding is the difference between total and nonspecific binding. Murine epidermal growth factor was a gift of Dr. Stanley Cohen (26). Human orosomucoid was a gift of Dr. Eugene Goldwasser (9). Human transferrin and porcine sodium insulin were purchased from Calbiochem-Behring, La Jolla, CA. Recombinant human insulinlike growth factor I came from AMGen Biologicals and rat insulinlike growth factor II was purchased from Collaborative Research, Inc., Lexington, MA. All experiments were performed with two to four replicates as indicated and SD were calculated for all means with more than two replicates. Significance was calculated using the $t$ test (27).

Electron microscopy. Cells in culture medium were mixed with an

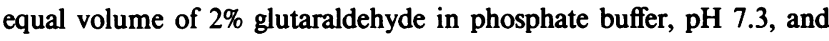
centrifuged to form a pellet. The pellet was resuspended in glutaraldehyde and incubated at $3^{\circ} \mathrm{C}$ for $2-3 \mathrm{~h}$. After secondary fixation in $1 \%$ Millonig's phosphate-buffered osmium tetroxide, the cells were stained en bloc with $0.5 \%$ aqueous uranyl acetate. The cells were then dehydrated and embedded in Araldite. Thin sections were stained with uranyl acetate and lead citrate and examined in an electron microscope (EM 200, Philips Medical Systems, Inc., Shelton, CT).

\section{Results}

Purification of BFU-E from human peripheral blood. Table I shows the mean yield and enrichment of BFU-E observed in four experiments when FH separated mononuclear cells were sequentially purified by depletion of sheep erythrocyte rosetteforming cells, surface immunoglobulin-positive cells, adherent cells, and cells bearing surface markers for the monoclonal antibodies CD2/OKT*11, CD11b/OKM*1, CD45R/My 11, and My 23. To determine the number of BFU-E, each fraction was cultured in the plasma clot system. Through these sequential depletion procedures human blood BFU-E were purified from
$0.017 \%$ (FH cells) to $0.368 \%$ ( $\mathrm{AB}^{-}$cells), a 22 -fold purification with a $43 \%$ yield. A high cell viability of $88-98 \%$ was maintained throughout the 24-h period of purification. BFU-E were cultured under conditions that favored erythroid growth, and using $\mathrm{AB}^{-}$ cells, non-BFU-E colonies were greatly reduced compared with cultures of $\mathrm{FH}$ cells.

Purification of erythroid colony-forming cells from day 9 cells generated in methylcellulose. Day 9 cells derived from methylcellulose cultures of $\mathrm{ERF}^{-}, \mathrm{SIg}^{-}, \mathrm{AD}^{-}$, and $\mathrm{AB}^{-}$cells were collected and further purified using adherence to plastic plates and density centrifugation (MC FH cells). To assay for erythroid colony-forming cells the MC FH cells were cultured in the plasma clot system in the presence of $\mathrm{rEp}$ at $1 \mathrm{U} / \mathrm{ml}$ for $6 \mathrm{~d}$ (until day 15). The MC cultures, which favored erythroid growth, gave rise to $43 \%$ erythroid colony forming cells by day 9 , and after adherence and density centrifugation in $\mathrm{FH}$, this was increased to $70 \%$ with a $77 \%$ yield (Table II). The MC cells and $\mathrm{MC} \mathrm{AD}^{-}$ cells contained both dead cells and cell debris, but these were greatly reduced in the MC FH cells. When FH mononuclear peripheral blood cells were cultured in MC without sequential depletion and were collected on day 9 for plating in plasma clots, there was a significant contamination with granulocytemacrophage colonies (Fig. $1 A$ ). However, the colonies derived from the culture of sequentially purified cells were almost entirely erythroid (Fig. $1 B$ ).

Morphology of erythroid colony-forming cells. By light microscopy (Fig. $1 C$ ), MC FH day 9 early erythroid cells were identified as extremely immature cells characterized by a fine nuclear chromatin, a well-defined large nucleolus, high nuclear/ cytoplasmic ratio, a perinuclear clear zone and basophilic cytoplasm with pseudopods. Although these cells varied in size and often had a vesicular, expanded cytoplasm that distorted the nucleus, they consistently retained these common features. Mature erythroid cells were identified by standard criteria (28). Proerythroblasts were distinguished from early erythroid cells by a smaller, less well defined nucleolus, and increased coarseness of the nuclear chromatin.

On electron microscopy (Fig. $2 A$ and $B$ ) the cell population of day $9 \mathrm{MC} \mathrm{FH}$ cells was composed of two major cell types. The first cell type was a primitive blast with a high nuclear/ cytoplasmic ratio, dispersed nuclear chromatin, and a prominent nucleolus (Fig. $2 \mathrm{~A}$ ). The cytoplasm contained clumps of mitochondria and the cell surface showed frequent pinocytotic ves-

Table I. Purification of BFU-E from Human Peripheral Blood

\begin{tabular}{|c|c|c|c|c|c|c|c|}
\hline \multirow[b]{2}{*}{ Cells } & \multicolumn{2}{|l|}{ Recovery } & \multirow[b]{2}{*}{ Viability } & \multirow[b]{2}{*}{ BFU-E } & & \multirow[b]{2}{*}{ Yield } & \multirow[b]{2}{*}{ Purification factor } \\
\hline & Cells & & & & & & \\
\hline & $\times 10^{-7}$ & $\%$ & $\%$ & per $10^{5}$ cells & $\%$ & $\%$ & \\
\hline FH & $46.8 \pm 15.6$ & 100 & $98 \pm 2$ & $17 \pm 7$ & 0.017 & 100 & \\
\hline ERF $^{-}$ & $20.7 \pm 9.5$ & $44.0 \pm 7.0$ & $98 \pm 0$ & $36 \pm 6$ & 0.036 & 95 & 2.12 \\
\hline $\mathrm{SIg}^{-}$ & $9.3 \pm 4.2$ & $20.0 \pm 5.0$ & $97 \pm 2$ & $54 \pm 13$ & 0.054 & 64 & 1.50 \\
\hline $\mathrm{AD}^{-}$ & $6.4 \pm 3.3$ & $14.0 \pm 4.0$ & $97 \pm 3$ & $85 \pm 15$ & 0.085 & 70 & 1.57 \\
\hline $\mathrm{AB}^{-}$ & $0.9 \pm 0.6$ & $1.9 \pm 0.6$ & $88 \pm 4$ & $368 \pm 33$ & 0.368 & 43 & 4.33 \\
\hline
\end{tabular}

FH interface mononuclear cells were sequentially fractionated to remove sheep erythrocyte rosette-forming cells (ERF ${ }^{-}$), cells with surface immunoglobulin $\left(\mathrm{SIg}^{-}\right)$, adherent cells $\left(\mathrm{AD}^{-}\right)$and cells with specific surface antigens for murine monoclonal antibodies $\mathrm{CD}_{11 \mathrm{~b} / \mathrm{OKM}}^{*} 1, \mathrm{CD}^{2} / \mathrm{OKT}^{*} 11$, $\mathrm{CD} 45 \mathrm{R} / \mathrm{My} 11$ and $\mathrm{My} 23\left(\mathrm{AB}^{-}\right)$by negative panning. Each fraction was cultured in the plasma clot system for $15 \mathrm{~d}$ with $2 \mathrm{U} / \mathrm{ml} \mathrm{rEp} \mathrm{and} 10 \%$ GCT conditioned medium. Mean values for four experiments \pm SD are shown. 


\begin{tabular}{|c|c|c|c|c|c|c|}
\hline \multirow[b]{2}{*}{ Cells } & \multicolumn{2}{|l|}{ Recovery } & \multirow[b]{2}{*}{ Viability } & \multirow{2}{*}{$\begin{array}{l}\text { Erythroid colony- } \\
\text { forming cells }\end{array}$} & \multirow[b]{2}{*}{ Yield } & \multirow[b]{2}{*}{ Purification factor } \\
\hline & Cell number $\times 10^{-7}$ & & & & & \\
\hline & & $\%$ & $\mathscr{H}$ & क & $\%$ & \\
\hline MC & $2.21 \pm 2.28$ & 100 & $75 \pm 11$ & $43 \pm 33$ & 100 & \\
\hline $\mathrm{AD}^{-}$ & $1.61 \pm 1.31$ & $73 \pm 12$ & $75 \pm 12$ & $38 \pm 19$ & 65 & 0.88 \\
\hline FH & $1.04 \pm 0.95$ & $47 \pm 9$ & $94 \pm 2$ & $70 \pm 18$ & 77 & 1.84 \\
\hline
\end{tabular}

Sequentially purified BFU-E were cultured for $9 \mathrm{~d}$ in methylcellulose (MC) and were then sequentially fractionated by adherence to plastic (AD ${ }^{-}$) and FH density centrifugation. Each fraction was cultured in triplicate in the plasma clot system with $1 \mathrm{U} / \mathrm{ml} \mathrm{rEp}$, until day 15 . Erythroid colonies of 2-64 cells were counted and mean values for six experiments \pm SD are shown.

icles (Fig. $2 A$, inset). Granules were absent. The second major cell type consisted of more differentiated erythroid cells which varied from proerythroblasts to polychromatophilic erythroblasts. These cells showed smaller, more rounded nuclei with marginated chromatin and more abundant cytoplasm (Fig. 2 $B$ ). There were frequent pinocytotic vesicles. Many of these cells showed focal accumulations of large vesicles containing debris, and occasional cells showed considerable glycogen, possibly methylcellulose deposition, within the cytoplasm. No ferruginous micelles were observed in the mitochondria. Cells in mitosis were occasionally present. Very rare mature polymorphonuclear and basophilic leukocytes were seen $(<7 \%$ of the total cell population). No monocytes or immature granulocytes were present.

The characteristics of the early erythroid cells resemble those of the undifferentiated cells derived from BFU-E colonies and plucked from methylcellulose cultures by Umemura et al. (8), as well as those of mouse CFU-E reported by Nijhof and Wierenga (29). Although the mouse CFU-E did not possess marked perinuclear clear zones like our cells and those of Umemura et al. (8), the former came directly from mice and the latter were derived from MC cultures. This difference is clarified by the electron microscopy where it is evident that the perinuclear clear zone consisted of debris probably pinocytosed in vitro.

Differential counts of Wright-stained cytocentrifuge preparations, and the percentages of erythroid cells of days 8-13 MC FH cells are shown in Table III. On days 8-13 of cell culture $92 \%$, or more, of these cells were recognized as erythroid cells. While day 8 cells had almost entirely early erythroid cells that appeared more immature than proerythroblasts, continued culture through day 13 led to progressive maturation to a preponderence of polychromatophilic and orthochromatic erythroblasts.

Plasma clot cultures of replicate days 8-13 cells were performed to enumerate the percentage of erythroid colonies and their cell number (Table IV). The culture of days 8-10 MC FH cells gave rise to a maximum percentage of erythroid colonies. By days 11-13 of cell culture, when the MC FH cells matured to late erythroblasts (Table III), a concomitant decline of early erythroid cells (Table III), the percentage of erythroid colonyforming cells (Table IV), and the size of the erythroid colonies (Table IV) were evident. Further culture of days 11-13 cells for a total of $5 \mathrm{~d}$ showed that the small colonies generated by mature erythroblasts did not have any further increase in cell number indicating that the length of cell culture was not limiting the size of these particular colonies.

A clear parallel relation was present between the number of early erythroid cells, the number and size of erythroid colonies, and also the number of CFU-E, by the classical definition of erythroid colonies consisting of 8-49 erythroblasts $(22,23)$. Since 56-59\% of the days 8-9 MC FH cells were CFU-E, these cells are identified by light and electron microscopy as the early erythroid cells of Table III. It is also evident that mature erythroblasts only gave rise to colonies with less than five cells, and that early erythroid cells gave rise to a fraction of erythroid colonies that were smaller than classical CFU-E colonies.

Growth characteristics of erythroid colony-forming cells. The relation between the number of erythroid colonies and the number of day $9 \mathrm{MC} \mathrm{FH}$ cells plated in plasma clots in a concentration range of 125 to 2,000 cells/ml was a straight line through the origin (Fig. $3 A$ ). An increase in the number of erythroid colonies was present after the addition of $10 \mathrm{mU} / \mathrm{ml}$ of $\mathrm{rEp}$ and a plateau was found at $1 \mathrm{U} / \mathrm{ml}$ (Fig. $3 \mathrm{~B}$ ). The plateau occurred when $75 \%$ of the cells plated had given rise to erythroid colonies, and most likely represents the full erythroid growth capacity that was present rather than any accumulated toxicity of the rEp preparation. No erythroid colonies were present without the addition of rEp.

Specific binding of ${ }^{125} I-r E p$ to days 8-13 erythroid colonyforming cells. Ep competition with ${ }^{125} \mathrm{I}-\mathrm{rEp}$ at $3^{\circ} \mathrm{C}$, using day 9 MC FH cells, is shown in Table V. A 210-fold excess of unlabeled pure Ep reduced the total ${ }^{125} \mathrm{I}-\mathrm{rEp}$ binding by $60 \%$. However, no inhibition occurred with BSA, FCS, and a variety of growth factors or glycoproteins at a similar concentration. The concentration dependence of the competition is shown in Table VI.

Fig. 4 and Table III demonstrate that the generation of erythroid colony-forming cells from MC cultures of sequentially depleted blood cells, after incubation for 8-13 d, reached a peak after 8-9 $d$ and declined progressively thereafter, while late erythroblasts increased. The specific binding of ${ }^{125} \mathrm{I}-\mathrm{rEp}$ to the MC FH cells was measured on days 8-13 and it was highest on days 8-9 when maximal erythroid colony-forming cells (70$85 \%$ ) were present. Specific binding declined in parallel with the decline of these cells, while other cells became the predominant population. Additional studies showed no specific binding of ${ }^{125} \mathrm{I}$-rEp to human blood $\mathrm{FH}$, erythrocyte rosette-forming, surface immunoglobulin positive, adherent, or antibody-coated cells, or to a variety of human hematopoietic cell lines (Sawada, K., and S. B. Krantz, unpublished observations), or mouse cell lines (9).

\section{Discussion}

The study of hematopoietic regulation has been hampered by the low frequency of the progenitor cells. In human bone mar- 

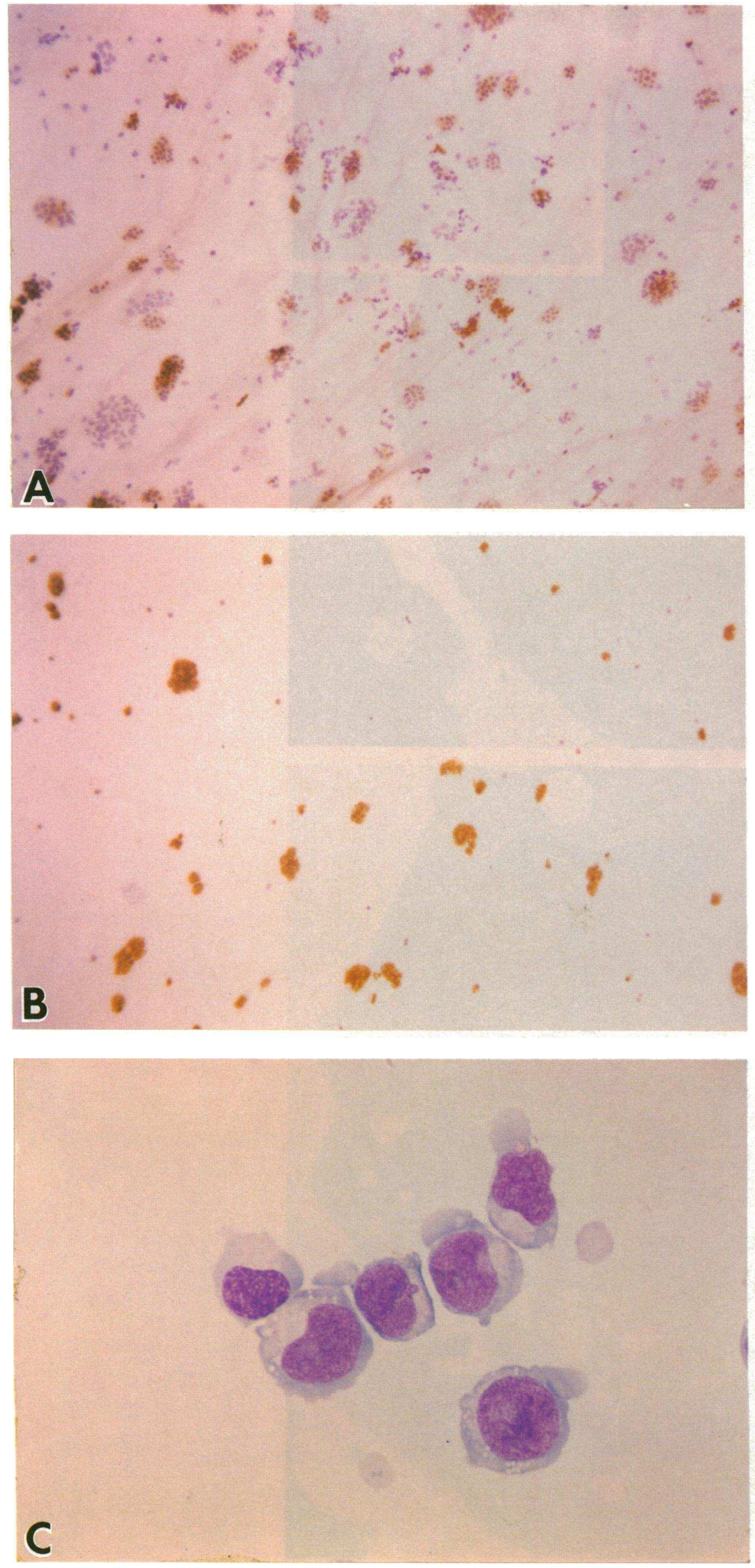

Figure 1. Comparison of colonies generated by human blood FH light density mononuclear cells $(A, \times 40)$, or sequentially depleted,

panned blood cells from same donor $(B, \times 40)$. The cells were cultured in MC until day 9, further purified by adherence and FH density sedimentation, and then incubated in plasma clots until day 15 , when they were fixed and benzidine stained. In the former case there was a significant contamination with granulocyte-macrophage colonies, as well as other cells $(A)$ while the latter gave rise to mostly erythroid colonies $(B)$. Replicate day 9 cells plated in $B$ were also Wright stained and were immature cells with fine nuclear chromatin, large nucleolus, high nuclear/cytoplasmic ratio, and a perinuclear clear zone, as well as mature erythroid cells $(C, \times 1000)$. 

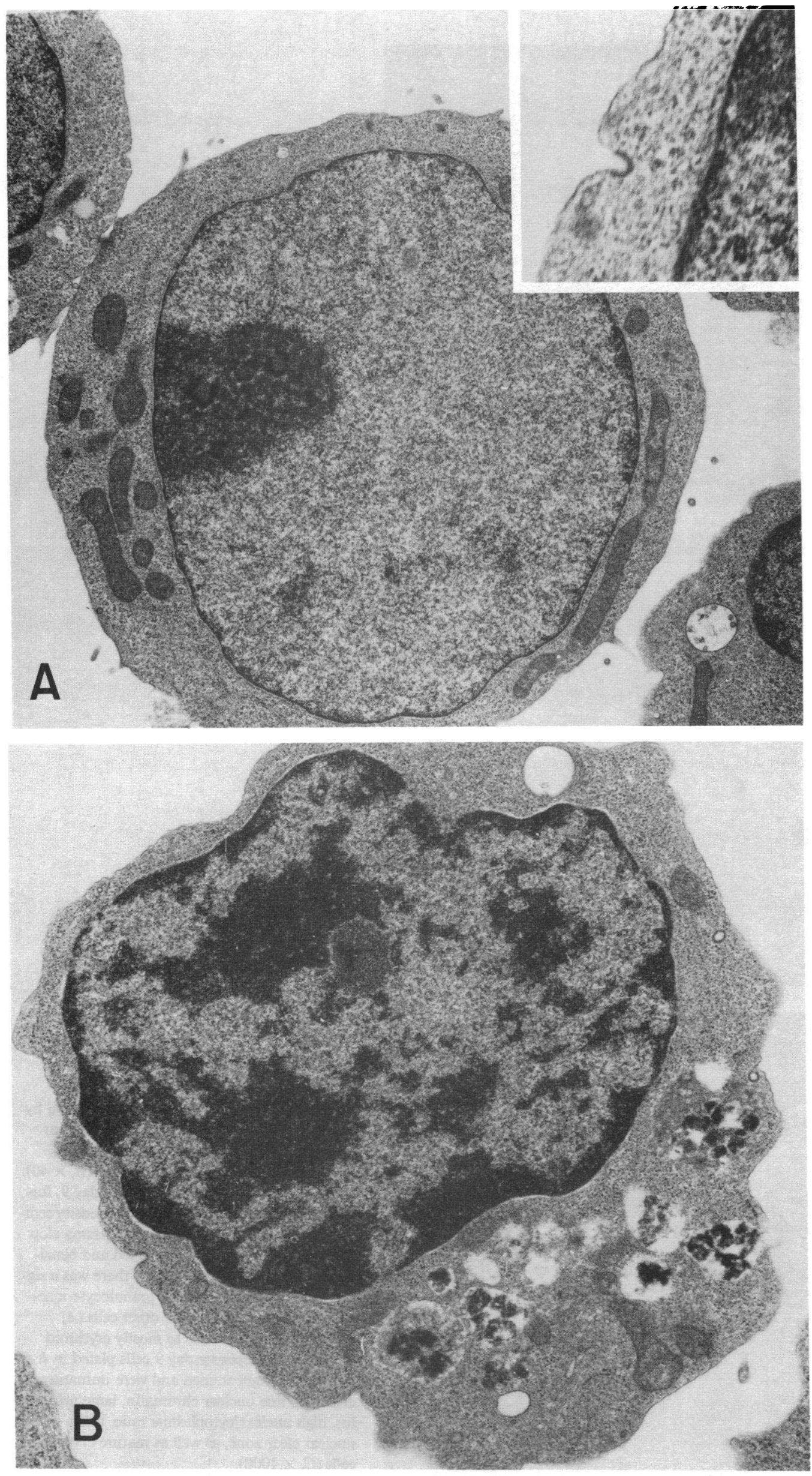

362 Sawada, Krantz, Kans, Dessypris, Sawyer, Glick, and Civin 
Table III. Differential Counts of Cells Derived from Methylcellulose Cultures after FH Enrichment

\begin{tabular}{|c|c|c|c|c|c|c|c|c|}
\hline $\begin{array}{l}\text { Days of } \\
\text { culture }\end{array}$ & $\begin{array}{l}\text { Early } \\
\text { erythroid cells }\end{array}$ & Proerythroblasts & $\begin{array}{l}\text { Basophilic } \\
\text { erythroblasts }\end{array}$ & $\begin{array}{l}\text { Polychromatophilic } \\
\text { erythroblasts }\end{array}$ & $\begin{array}{l}\text { Orthochromatophilic } \\
\text { erythroblasts }\end{array}$ & Macrophages & Granulocytes & Others \\
\hline 8 & 87.5 & 2.0 & 2.5 & 0 & 0 & 4.0 & 3.5 & 0.5 \\
\hline 9 & 61.5 & 16.5 & 15.5 & 0 & 0 & 1.0 & 5.0 & 0.5 \\
\hline 10 & 36.5 & 29.0 & 22.0 & 8.0 & 0 & 0.5 & 4.0 & 0 \\
\hline 11 & 15.5 & 20.5 & 27.5 & 31.5 & 3.5 & 0.5 & 1.0 & 0 \\
\hline 12 & 4.5 & 17.0 & 26.5 & 40.5 & 4.5 & 2.5 & 4.0 & 0.5 \\
\hline 13 & 0 & 0.5 & 2.5 & 83.0 & 8.0 & 0.5 & 5.5 & 0 \\
\hline
\end{tabular}

Sequentially fractionated peripheral blood day 1 cells were cultured in methylcellulose with $10 \%$ GCT-conditioned medium and $2 \mathrm{U} / \mathrm{ml}$ of $\mathrm{rEp}$ for 8-13 d. The generated cells were collected and purified by adherence to plastic and Ficoll-Hypaque centrifugation. After Wright stain of cytocentrifuge preparations differential counts of 200 cells were made. Early erythroid cells were identified as immature blasts with a fine nuclear chromatin, well defined large nucleolus and high nuclear/cytoplasm ratio. Mature erythroid cells were identified by standard criteria (28). Cells cultured for 8-9 d had more than $60 \%$ early erythroid cells while more extensive culture led to a predominance of mature erythroblasts.

row, blood, and fetal liver, only $0.1-1.0 \%$ of the cells are early erythroid progenitor cells $(4-6,10,30)$. Identification and accurate characterization of the human Ep receptor have lagged mainly because of a lack of sufficient purity and quantity of these cells. Methods used in the purification of normal progenitor cells have included density gradient centrifugation (10), immune rosetting (31), fluorescence-activated cell sorting (32), negative or positive selection by panning $(4,5,33)$, and various combinations of these physical and immunologic techniques $(4,5,34)$. While these techniques have led to a significant progenitor enrichment, cell yields have been notably low $(5,6)$, particularly for the study of Ep binding to BFU-E or CFU-E.

In mice, CFU-E have been purified in large numbers, but this has required either the administration of thiamphenicol and phenylhydrazine (29), which greatly elevates Ep levels, or the infusion of a Friend virus strain that leads to a huge accumulation of CFU-E in the spleen (3). In human beings erythroid bursts have been plucked after $7 \mathrm{~d}$ of incubation in methylcellulose with Ep and have provided up to $5 \times 10^{5}$ of these cells (8), but larger numbers of purified human CFU-E have not been available. Based on the use of murine spleen cells infected by the anemia strain of the Friend virus (9), we estimated that the number of erythroid progenitor cells that are necessary for an Ep binding study would be $\sim 10^{7}$ and that the purification of CFU-E from normal human bone marrow would need $>2 \times 10^{9}$ bone marrow nucleated cells as starting cells assuming that the recovery was $100 \%$. Under these circumstances it would be difficult to find sufficient normal donors to develop purification procedures and to conduct a suitable study.

For these reasons we began with the blood as a starting tissue. It was more readily available, and although CFU-E are not present in normal human blood, they can be derived from BFU-E $(7,8)$. Indeed, the lack of erythroid progenitor cells other than BFU-E, in the blood, favored the purification of CFU-E in a relatively uniform state of development. The relatively common procedures of FH centrifugation and sheep erythrocyte rosetteforming cell depletion removed large numbers of contaminant red cells, platelets, granulocytes, and $\mathrm{T}$ lymphocytes with little loss of BFU-E. Surface immunoglobulin-positive cell depletion removed B cells and other cells containing Fc receptors while enriching the BFU-E by 1.5 -fold. Overnight adherence lost little useable laboratory time or BFU-E, and removed mainly monocytes (13) to enhance the purification by another 1.5 -fold. Additional contaminant cells were removed by the relatively simple method of negative panning that depended on the antibodies that were utilized. Many murine monoclonal antibodies (CD1 lb/ $\mathrm{OKM}^{*} 1, \mathrm{CD} 3 / \mathrm{OKT}^{*} 3, \mathrm{CD}^{*} / \mathrm{OKT}^{*} 8, \mathrm{CD}^{2} / \mathrm{OKT}^{*} 11$ [Ortho], CD5/Leu 1, CD2/Leu 5B, CD7/Leu 9, CD19/Leu 12, Leu 19 [Becton Dickinson and Co.], CD45R/My 11 (17), CD15/My 18 [33], and My 23) to surface hematopoietic cell antigens were tried, at a variety of concentrations and volumes, and four were chosen as most useful: $\mathrm{CD} 11 \mathrm{~b} / \mathrm{OKM}^{*} 1$, which is directed to an antigen on monocytes, granulocytes, and natural killer cells $(14$, 15); CD2/OKT*11, which is directed to the sheep erythrocyte receptor on T cells (16); CD45R/My 11, which removed CFUGM and many $B$ lymphocytes that expressed the My 11 antigen (17); and My 23, which removed mature granulocytes and monocytes. Purification of the blood BFU-E not only removed other progenitor cells whose colonies would dilute the CFU-E, but also reduced the total number of nucleated cells that had to be cultured for 8-10 days, and thereby reduced the magnitude and expense of the procedure.

Enhancement of CFU-E purity to 56-59\% was not only dependent on these purification procedures, but also on 8-9 d of culture with $\mathrm{rEp}$, which progressively expanded and enhanced the erythroid cell compartment. Optimum concentrations of GCT and rEp were added based on dose-response curves and with this medium a small percentage of the large erythroid bursts that grew in methylcellulose were mixed with granulocytes and megakaryocytes. These were not counted separately since our aim was to derive CFU-E irrespective of the source. Initially all of the preceding antibodies also were used for negative panning on day 9, but provided little increase in CFU-E purity. Adherence to Sephadex G-10 also was of little benefit. For this reason only adherence to plastic plates and FH density centrifugation were used after MC culture and these methods removed monocytes, macrophages, late erythroblasts, dead cells, and cell debris.

Whereas most experiments that have reported CFU-E num-

Figure 2. Electron microscopy of day 9 erythroid colony-forming cells. $(A)$ Blast cell with prominent nucleolus $(\times 14,500)$. Inset shows surface pinocytotic vesicle, $(\times 51,000)$. (B) Later recognizable erythroblast with frequent surface pinocytosis and debris-containing vesicles $(\times 26,600)$. 
Table IV. Proliferative Capacity of Erythroid Colony-Forming Cells Derived from Methylcellulose Cultures after FH Enrichment

\begin{tabular}{|c|c|c|c|c|c|c|}
\hline \multirow{2}{*}{$\begin{array}{l}\text { Days of } \\
\text { culture }\end{array}$} & \multicolumn{5}{|c|}{ Cell number of erythroid colonies } & \multirow{2}{*}{$\begin{array}{l}\text { Erythroid colonies } \\
\text { Nucleated cells plated }\end{array}$} \\
\hline & $2-4$ cells & 5-7 cells & $8-16$ cells & $17-49$ cells & $50+$ cells & \\
\hline & $\%$ & $\%$ & $\%$ & $\%$ & $\%$ & $\%$ \\
\hline 8 & 27 & 13 & 46 & 13 & 1 & 70 \\
\hline 9 & 30 & 14 & 53 & 3 & 0 & 85 \\
\hline 10 & 52 & 24 & 23 & 1 & 0 & 49 \\
\hline 11 & 90 & 5 & 5 & 0 & 0 & 29 \\
\hline 12 & 94 & 6 & 0 & 0 & 0 & 13 \\
\hline 13 & 98 & 2 & $\mathbf{0}$ & 0 & 0 & 2 \\
\hline
\end{tabular}

Replicate cells from the experiment in Table III were cultured in plasma clots in the presence of $1 \mathrm{U} / \mathrm{ml}$ of rEp until day 15. Clots were fixed, stained by benzidine, and the number of hemoglobin-containing cells per colony were counted. Cells harvested after 8-9 d of culture gave rise to 56-59\% CFU-E (erythroid colonies of 8-49 cells), while cells cultured for a more extensive period gave rise to smaller erythroid colonies.

bers have not provided an independent measure of the number of these cells beyond a count of their descendent colonies, our method does provide such a measure. First, the cells that are plated are almost entirely single under the inverted microscope, and the cell concentration curve, with the plating of as few as $60-1,000$ cells/well, is a straight line through the origin indicating that each colony arose from a single cell. Secondly, in some experiments $<7 \%$ of the cells, by light or electron microscopy had an appearance of nonerythroid, nonhomogeneous cells, and the total cell population provided $85 \%$ erythroid colonies. Thirdly, GM-CSF addition to replicate cells, without Ep, produced only an occasional very small granulocyte-macrophagecolony $(<0.5 \%)$, and no megakaryocyte colonies were evident under conditions that favored their development (Dessypris, E. N., K. Sawada, and S. B. Krantz, unpublished data). Finally, days 8-9 erythroid colony-forming cells consisted of 56-59\% CFU-E and had $62-88 \%$ pure early erythroid cells by light microscopy, with both numbers declining in parallel. The difference in these figures represent mostly the formation of smaller erythroid colonies, but the definition of a CFU-E as a cell that gives rise to erythroid colonies of $8-49$ cells is arbitrary. It is not unreasonable to think that some CFU-E have a probability of less replication and will behave like more mature erythroid cells even

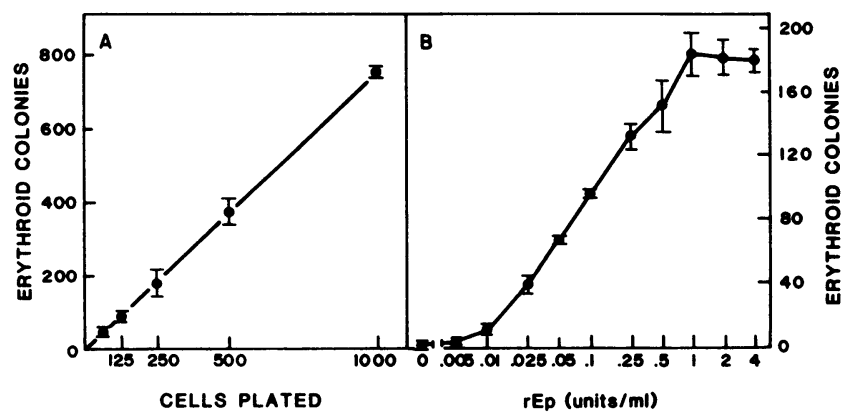

Figure 3. Relation between the number of erythroid colonies and the number of day $9 \mathrm{MC} \mathrm{FH}$ cells plated $(A)$, and the concentration of Ep $(B)$. The cells were plated in $0.5 \mathrm{ml}$ plasma clots in concentrations of $62-1,000$ cells/well with $1 \mathrm{U} / \mathrm{ml}$ of $\operatorname{rEp}(A)$ or 250 cells/well with a range of concentrations of $\mathrm{rEp}(B)$ and were incubated at $37^{\circ} \mathrm{C}$ in a high humidity, $5 \% \mathrm{CO}_{2}, 95 \%$ air incubator for $6 \mathrm{~d}$. Each value is the mean of three replicates \pm SD. though they are at a similar stage of development as other "traditional" CFU-E. Nevertheless, to accommodate this traditional definition we have defined our days 8-13 cells as erythroid colony-forming cells with CFU-E as a subset. Alternatively, it is possible that some of the early erythroid cells were further developed chemically than was apparent by light microscopy.

These studies not only provide an independent measure of CFU-E by direct microscopy and enumeration, but they also provide sufficient numbers of these cells to demonstrate specific Ep binding sites. The ${ }^{125} \mathrm{I}-\mathrm{rEp}$ that was used retained more than $95 \%$ of its biologic activity (25), and specificity of binding was shown by the uniqueness of competition for binding by pure Ep and the direct relation of the amount of specific binding to the number of erythroid colony-forming cells. It appears that little Ep specific binding to late erythroblasts occurs, which is compatible with experiments using murine cells (35). This is the first

Table V. Specificity of ${ }^{125}$ I-rEp Binding to Cells Derived from Methylcellulose Cultures after FH Enrichment

\begin{tabular}{ll}
\hline Addition & Total binding \\
\hline & $c p m$ \\
None & $252 \pm 15$ \\
Erythropoietin $(80 \mathrm{nM})$ & $105 \pm 19$ \\
Albumin $(0.25 \%)$ & $241 \pm 22$ \\
Fetal bovine serum (2.5\%) & $243 \pm 18$ \\
Orosomucoid (80 $\mathrm{nM})$ & $248 \pm 18$ \\
Epidermal growth factor $(80 \mathrm{nM})$ & $237 \pm 16$ \\
Insulin (80 nM) & $240 \pm 13$ \\
Transferrin $(80 \mathrm{nM})$ & $251 \pm 30$ \\
Insulinlike growth factor-I (80 nM) & $234 \pm 8$ \\
Insulinlike growth factor-II (80 nM) & $201 \pm 31$ \\
\end{tabular}

${ }^{125} \mathrm{I}-\mathrm{rEp}(0.38 \mathrm{nM})$ was incubated at $3^{\circ} \mathrm{C}$ with $4.6 \times 10^{5}$ purified day 9 cells in $50 \mu \mathrm{l}$ of IMDM with the above additions. Erythropoietin was the purified human urinary hormone at $70,000 \mathrm{U} / \mathrm{mg}$ protein. After 8 $h$ the cells were layered on $0.9 \mathrm{ml}$ of $10 \%$ BSA and centrifuged at $15,300 \mathrm{~g}$ for $4 \mathrm{~min}$. The tubes were frozen and the cell pellets were cut off for measurement of radioactivity. Each value is the mean \pm SD for four replicates. The difference between 252 and $105 \mathrm{cpm}$ is significant $(P<0.001)$ while other differences are not significant $(P>0.1)$. Replicate cells cultured in triplicate gave rise to $53 \pm 3 \%$ erythroid colonies. 
Table VI. Competition for Binding Sites by Unlabeled rEp

\begin{tabular}{ll}
\hline Unlabeled rEp & Total binding \\
\hline$n M$ & $c p m$ \\
0 & $372 \pm 32$ \\
0.26 & $157 \pm 24$ \\
2.6 & $174 \pm 39$ \\
12.8 & $134 \pm 17$ \\
25.5 & $114 \pm 35$ \\
\hline
\end{tabular}

${ }^{125} \mathrm{I}$-rEp $(0.51 \mathrm{nM})$ was incubated at $3^{\circ} \mathrm{C}$ with $2.2 \times 10^{5}$ purified day 9 cells in $50 \mu \mathrm{l}$ of standard medium containing various concentrations of unlabeled $\mathrm{rEp}(10,000 \mathrm{U} / \mathrm{mg})$ for $16 \mathrm{~h}$ before measurement of total ${ }^{125} \mathrm{I}-\mathrm{rEp}$ binding. Total binding is the mean $\pm \mathrm{SD}$ for three replicates.

demonstration of specific Ep binding to human CFU-E, but further studies are necessary to characterize the number, dissociation constant(s) and molecular size of these putative human Ep receptors.

We believe that these studies have important implications for the study of normal erythropoiesis in human beings and the study of a wide variety of anemias and polycythemias. First, this work should enhance the investigation of normal erythroid development by permitting the study of the sequence of chemical events during normal human terminal erythroid differentiation using peripheral blood, a readily available source of cells. Second, the normal sequence can be compared to the sequence of developmental events in individuals with a diverse number of anemias and polycythemias as long as they have erythroid progen-

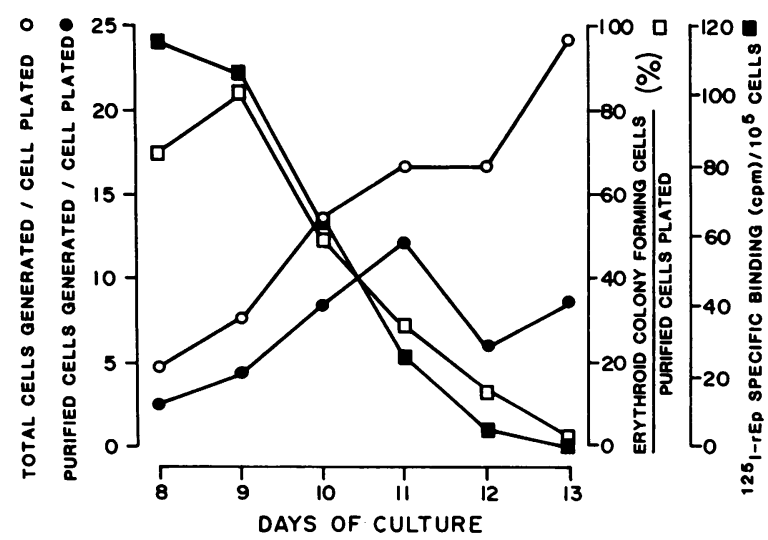

Figure 4. Specific binding of ${ }^{125}$ I-rEp to days 8-13 erythroid colonyforming cells. Sequentially fractionated peripheral blood day 1 cells were cultured in MC in the presence of $10 \%$ GCT-conditioned medium and $2 \mathrm{U} / \mathrm{ml}$ of rEp for 8-13 d. All of the generated cells (0) were collected, purified as post Ficoll-Hypaque cells (๑), plated in duplicate in 0.5-ml plasma clots, and cultured in the presence of $1 \mathrm{U} / \mathrm{ml}$ of rEp until fixation and benzidine staining on day $15 .{ }^{125} \mathrm{I}-\mathrm{rEp}$ (1.32 nM) was incubated at $37^{\circ} \mathrm{C}$ with quadruplicates of $3.0 \times 10^{5}$ purified cells in $50 \mu \mathrm{l}$ of medium. After $2 \mathrm{~h}$ the amount of ${ }^{125} \mathrm{I}$-rEp bound to the purified cells was measured. Nonspecific binding was measured with replicates that had an 80-fold excess of rEp and was subtracted from total binding to determine specific binding. The percentage of erythroid colony-forming cells $(\square)$ was at its highest by 8-9 d (70\%). When the specific binding of ${ }^{125} \mathrm{I}-\mathrm{rEp}$ ( $(0)$ was measured during this time it was also greatest on days 8-9 and declined in parallel with the decline of these cells while other cells $(\bullet)$ increased. itors that grow in vitro. Finally, the number and quality of the Ep receptors on human CFU-E can be studied in individuals with anemia and polycythemia to characterize further those disorders, such as polycythemia vera, that might have a defect in this system, in order to define further a hypersensitivity (36), or reduced sensitivity (37) to Ep. The present studies not only show the morphology and the presence of specific binding of Ep to normal CFU-E, but should lead to a more precise understanding and definition of the defects present in a number of disorders of erythropoiesis and, perhaps, more effective treatment, which is our ultimate aim.

\section{Acknowledgments}

The authors thank Eugene Goldwasser for his generous gift of purified human urinary Ep, Ms. Sharon Horn for her excellent technical assistance that made these studies possible, and Ms. Mary Wilson for her assistance in the preparation of this manuscript.

This work was supported by VA Medical Research Funds, grants AM-15555, T32-07186, RR-95, and CA-32318 from the National Institutes of Health, and by grant 1418 from the Council for Tobacco Research USA, Inc. Dr. Civin is a Scholar of the Leukemia Society of America, Inc.

\section{References}

1. Miyake, T., C. K.-H. Kung, and E. Goldwasser. 1977. Purification of human erythropoietin. J. Biol. Chem. 252:5558-5564.

2. Jacobs, K., C. Shoemaker, R. Rudersdorf, S. D. Neill, R. J. Kaufman, A. Mufson, F. Seehra, S. S. Jones, R. Hewrick, E. F. Fritsch, M. Kawakita, T. Shimizu, and T. Miyake. 1985. Isolation and characterization of genomic and cDNA clones of human erythropoietin. Nature (Lond.). 313:806-810.

3. Koury, M. J., S. T. Sawyer, and M. C. Bondurant. 1984. Splenic erythroblasts in anemia-inducing Friend disease: A source of cells for studies of erythropoietin-mediated differentiation. J. Cell. Physiol. 121: 526-532.

4. Emerson, S. G., C. A. Sieff, E. A. Wang, G. W. Wong, S. C. Clark, and D. G. Nathan. 1985. Purification of fetal hematopoietic progenitors and characterization of recombinant multipotential colony-stimulating activity. J. Clin. Invest. 76:1286-1290.

5. Sieff, C. A., S. G. Emerson, A. Mufson, T. G. Gesner, and D. G. Nathan. 1986. Dependence of highly enriched human bone marrow progenitors on hemopoietic growth factors and their response to recombinant erythropoietin. J. Clin. Invest. 77:74-81.

6. Tepperman, A. D., J. E. Curtis, and E. A. McCulloch. 1974. Erythropoietic colonies in cultures of human marrow. Blood. 44:659669.

7. Bondurant, M., M. Koury, S. B. Krantz, T. Blevins, and D. T. Duncan. 1983. Isolation of erythropoietin-sensitive cells from Friend virus-infected marrow cultures: characteristics of the erythropoietin response. Blood. 61:751-758.

8. Umemura, T., K. Umene, J. Nishimura, Y. Fukumaki, Y. Sakaki, and $\mathrm{H}$. Ibayashi. 1986. Expression of c-myc oncogene during differentiation of human burst-forming unit, erythroid (BFU-E). Biochem. Biophys. Res. Commun. 135:521-526.

9. Krantz, S. B., and E. Goldwasser. 1984. Specific binding of erythropoietin to spleen cells infected with the anemia strain of Friend virus. Proc. Natl. Acad. Sci. USA. 81:7574-7578.

10. Clark, B. J., and D. Housman. 1977. Characterization of an erythroid precursor cell of high proliferative capacity in normal human peripheral blood. Proc. Natl. Acad. Sci. USA. 74:1105-1109.

11. Mendes, N. F., M. E. A. Tolnai, N. P. A. Silveira, R. B. Gilbertsen, and R. S. Metzgar. 1973. Technical aspects of the rosette tests used to detect human complement receptor (B) and sheep erythrocyte-binding (T) lymphocytes. J. Immunol. 111:860-867. 
12. Chess, L., R. P. MacDermott, and S. F. Schlossman. 1974. Immunologic functions of isolated human lymphocyte subpopulations. I. Quantitative isolation of human $\mathrm{T}$ and $\mathrm{B}$ cells and response to mitogens. J. Immunol. 113:1113-1121.

13. Koller, C. A., and A. F. LoBuglio. 1981. Monocyte-mediated antibody-dependent cell-mediated cytotoxicity. The role of the metabolic burst. Blood. 58:293-299.

14. Breard, J., E. L. Reinherz, P. C. Kung, G. Goldstein, and S. F. Schlossman. 1980. A monoclonal antibody reactive with human peripheral blood monocytes. J. Immunol. 124:1943-1948.

15. Van De Griend, R. J., I. Ten Berge, H. J. Tanke, D. Roos, P. Th. A. Schellekens, C. J. M. Melief, W. P. Zeijlemaker, and A. Astaldi. 1982. Characterization of two subsets of human T cells. J. Immunol. 128:1979-1985.

16. Verbi, W., M. F. Greaves, C. Schneider, K. Koubek, G. Janossy, H. Stein, P. Kung, and G. Goldstein. 1982. Monoclonal antibodies OKT 11 and OKT $11 \mathrm{~A}$ have pan-T reactivity and block sheep erythrocyte "receptors." Eur. J. Immunol. 12:81-86.

17. Strauss, L. C., C. Brovall, M. J. Fackler, J. F. Schwartz, J. H. Shaper, M. R. Loken, and C. I. Civin. 1986. Antigenic analysis of hematopoiesis. IV. The My-11 hematopoietic cell surface antigen is expressed by myelomonocytic and lymphoid, but not erythroid progenitor cells. Exp. Hematol. 14:935-945.

18. Wysocki, L. J., and V. L. Sato. 1978. "Panning" for lymphocytes: a method for cell selection. Proc. Natl. Acad. Sci. USA. 75:2844-2848.

19. McLeod, D. L., M. M. Shreeve, and A. A. Axelrad. 1974. Improved plasma culture system for production of erythrocytic colonies in vitro. Quantitative assay method for CFU-E. Blood. 44:517-534.

20. Iscove N. N., F. Sieber, and K. H. Winterhalter. 1974. Erythroid colony formation in cultures of mouse and human bone marrow: analysis of the requirement for erythropoietin by gel filtration and affinity chromatography on agarose-concanavalin A. J. Cell. Physiol. 83:309-320.

21. Zaentz, S. D., J. A. Luna, A. S. Baker, and S. B. Krantz. 1977. Detection of cytotoxic antibody to erythroblasts. J. Lab. Clin. Med. 89: 851-860.

22. Ogawa, M., M. D. MacEachern, and L. Avila. 1977. Human marrow erythropoiesis in culture: II. Heterogeneity in the morphology, time course of colony formation, and sedimentation velocities of the colony-forming cells. Am. J. Hematol. 3:29-36.

23. Eaves, A. C., and C. J. Eaves. 1984. Erythropoiesis in culture. Clinics Haematol. 13:371-391.
24. Sherwood, J. B., and E. Goldwasser. 1979. A radioimmunoassay for erythropoietin. Blood. 54:885-893.

25. Sawyer, S. T., S. B. Krantz, and E. Goldwasser. 1987. Binding and receptor-mediated endocytosis of erythropoietin in Friend virus infected erythroid cells. J. Biol. Chem. 262:5554-5562.

26. Savage, C. R., Jr., and S. Cohen. 1972. Epidermal growth factor and a new derivative. Rapid isolation procedure and biological and chemical characterization. J. Biol. Chem. 247:7609-7611.

27. Snedecor, G. W., and W. G. Cochran. 1967. Statistical Methods. Iowa State University Press, Ames. 6th ed.

28. Wintrobe, M. M., G. R. Lee, D. R. Boggs, T. C. Bethell, J. Foerster, J. W. Athens, and J. N. Lukens. 1981. Clinical Hematology. Lea and Febiger, Philadelphia. 8th ed. 108-112.

29. Nijhof, W., and P. K. Wierenga. 1983. Isolation and characterization of the erythroid progenitor cell: CFU-E. J. Cell Biol. 96:386392.

30. Hasson, M. W., J. D. Lutton, R. D. Levere, R. F. Rieder, and L. L. Cederquist. 1979. In vitro culture of erythroid colonies from human fetal liver and umbilical cord blood. Br. J. Haematol. 41:477-484.

31. Griffin, J. D., R. P. Beveridge, and S. F. Schlossmann. 1982. Isolation of myeloid progenitor cells from peripheral blood of chronic myelogenous leukemia patients. Blood. 60:30-37.

32. Beverly, P. C. L., D. Linch, and D. Delia. 1980. Isolation of human haemopoietic progenitor cells using monoclonal antibodies. $\mathrm{Na}$ ture (Lond.). 287:332-333.

33. Strauss, L. C., R. K. Stuart, and C. I. Civin. 1983. Antigenic analysis of hematopoiesis. I. Expression of the My-1 granulocytic surface antigen on human marrow cells and leukemic cell lines. Blood. 61:12221231.

34. Nicola, N. A., D. Metcalf, H. Von Melchner, and A. W. Burgess. 1981. Isolation of murine hemopoietic progenitor cells and selective fractionation of various erythroid precursors. Blood. 58:376-386.

35. Weiss, T. L., C. K.-H. Kung, and E. Goldwasser. 1985. The frequency of bone marrow cells that bind erythropoietin. J. Cell. Biochem. 27:57-65.

36. Zanjani, E. D., J. D. Lutton, R. Hoffman, and L. R. Wasserman. 1977. Erythroid colony formation by polycythemia vera bone marrow in vitro. J. Clin. Invest. 59:841-848.

37. Nathan, D. G., B. J. Clarke, D. G. Hillman, B. P. Alter, and D. E. Housman. 1978. Erythroid precursors in congenital hypoplastic (Diamond-Blackfan) anemia. J. Clin. Invest. 61:489-498. 